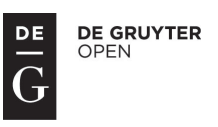

\title{
The ReVENUE Side OF A UNIVERSAL BASIC INCOME IN THE EU AND EURO AREA
}

\author{
Jože Mencinger ${ }^{1}$
}

\begin{abstract}
This paper tries to answer the question of whether universal basic income on the European level is a realistic option or an illusion. As UBI implies a much larger EU budget and a redistribution of collected budget revenues, the chance of introducing UBI depends on the required redistribution - the larger the redistribution, the lower the chance. The chance is indirectly assessed by an exercise in which 50 percent of actual tax revenues generated by indirect taxes of member states is collected at the center and distributed equally to all citizens. Though the net costs to the rich are relatively modest, the results indicate that the idea of introducing UBI on the European level is an illusion.
\end{abstract}

\section{Keywords}

Universal Basic Income, Fiscal Union, Indirect Taxes, Income Distribution

\section{Introduction}

Universal basic income (UBI) was proposed by Phillip van Parijs in 2001 in the book "What's Wrong with a Free Lunch?" and was discussed and mainly welcomed by several well-known economists, including Robert Solow and Edmund Phelps (van Parijs, 2001). Definitions of UBI differ; so let us use the definition from the cover of a book published in $2004^{2}$. "More specifically, it is a proposal that the state pays a fixed monthly sum of money to all citizens (or residents) aged (for example) sixteen years and older. This payment would not be subject to any type of behavior or specific features, the recipient should only be an eligible member of the society".

The idea of UBI is in a way less new than it seems at first glance. It is a mild version of the communist "contribution according to abilities and distribution according to needs" or a more radical version of what is known as a social market economy. In such an economy,

\footnotetext{
${ }^{1}$ University of Ljubljana, Faculty of Law, Poljanski nasip 2, 1000 Ljubljana, Slovenia, and EIPF, Prešernova cesta 21, 1000 Ljubljana, Slovenia. E-mail: joze.mencinger@eipf.si.

${ }^{2}$ In Slovenia, the idea of UBI re-emerged in 2004 in "Free lunch for all?" edited by Igor Pribac.
} 
some goods and services, for example, health and education, are public goods, and citizens are guaranteed the minimum social security. UBI is similar, but is slightly more radical than a universal pension based only on age, which is the pillar of the Beveridge pension model, or universal child benefits.

Could the world afford a "free lunch" or UBI for every person on earth regardless of property status and ability to generate income? The answer is, probably, yes. Would this be possible in Europe? The answer is similar. Probably, yes.

\section{But...}

There are many questions which should be addressed. Would UBI be added to current public social, health and educational services, or would it replace them? In the first case, we have to think primarily of the revenue side, in the second case, we have to deal with the expenditure side of UBI.

In the first case, we are therefore interested in how to obtain the money. UBI implies additional taxation and redistribution. What the additional taxation and redistribution would amount to depends on the size of the UBI and the structure of taxes, but there is no doubt that UBI would require much higher taxation ${ }^{3}$.

How abundant would the "free lunch" be? At subsistence level? This differs from country to country and is also constantly changing. "A rich guy" in Bangladesh is very likely poorer than "a poor guy" in Switzerland. Subsistence level is approximated by GDP/capita. Even within the EU the differences are enormous: in Luxembourg, GDP/capita is approximately $€ 55,000$, in Lithuania it is $€ 4,800$, while adjusted by purchasing power it is $€ 45,000$ in Luxembourg and $€ 10,000$ in Lithuania.

If the level of the UBI were lower than the respective subsistence level, it would not affect the dilemma of "more efforts or more leisure", an issue discussed in some recent papers (Gilroy, 2013; Standing, 2012). If, however, the UBI were above subsistence level, a proportion of the population might replace work with idleness, which would reduce the supply of labor. This might not be bad, but it is unlikely that such arrangements would be easily adopted by the part of the population which would work and pay higher taxes for those who would meet their needs with UBI.

If UBI replaces the current system of social security, different issues arise. The existing social security system is based on the classification of goods and services as "more or less useful and necessary" and on ideas of social justice. It is therefore a matter of value judgments which have been developed for decades or even centuries. Even among economically approximately equally developed countries, the notion of what is a socially equitable distribution of income and wealth varies greatly. This is reflected in the shares of the public sector in GDP, as the shares largely determine the abundance of a "free lunch" in a society. In Scandinavian countries, the share is in excess of 50 percent of GDP, in the US, the share is 30 percent. The shares have changed over time and according to economic cycles. Thus, between the end of World War II and the mid-eighties, the shares of the

\footnotetext{
${ }^{3}$ Take, for example, UBI of $€ 200$ per month and that all Slovenian citizens, irrespective of age, would be eligible. This would require $€ 4.8$ billion per year, or 13 percent of GDP, about as much as the pension fund, and increase the Slovenian share of public expenditure in GDP to Scandinavian levels.
} 
public sector in GDP of developed countries doubled or even tripled. Since then, they have been stagnating or declining, influenced by the dominant ideology of the "self-evident" efficiency of the private and "self-evident" inefficiency of the public sector.

The idea that the increase in transaction costs in the modern world is socially useful rather than harmful is considered nonsense not only by a very prominent institutional school of economics but also by the large majority of economists discussing the theoretical aspects of UBI (Zwolinski, 2012; Munger, 2012). However, one cannot overlook the fact that only the constant creation of new products and needless services (private or public) ensures the functioning of contemporary economies.

Discussion of UBI also leads to the question of the "usefulness" of certain jobs. Indeed, we have to increasingly invent new jobs to neutralize the effects of technological change on employment, which would, without inventing new services, result in the so-called one-fifth society. The salaries of public servants are usually regarded as a burden on the economy, a view which is particularly popular among managers of privately owned companies. According to the views expressed by their associations, useless public servants should be grateful to employers in the private sector. On the other hand, it is almost certain that a civil servant doing nothing is far less harmful than a financier who engages in the honorable and most profitable activity of financial deepening - stevedoring money from one drawer to another.

At least in theory, UBI would be superior to the existing system of public goods and social security, as it would enable recipients to choose between public goods and maximizing utility in consumption, which should ensure Pareto optimality. What remains open is the temporal dimension of maximizing utility: the consumption structure of a young healthy recipient of UBI would differ from the consumption structure of an elderly ailing recipient. Many believe that, in a period of economic, social and political crisis, UBI is totally irrational. Should we therefore wait until the end of the crisis and for an economic boom to introduce UBI? The answer is no. The introduction of UBI in a period of economic crisis, when it is clear that we lack aggregate demand, is no doubt a much better way to increase aggregate demand than so-called "quantitative easing" - a policy of the ECB that will most likely create new financial bubbles rather than increase aggregate demand. UBI might not significantly increase aggregate demand, but it is perhaps the right way to lessen the social effects of the crisis and add to the creation of a new economic order. Indeed, UBI is relevant because of the crisis, in which all the "smart" solutions proposed by global financial institutions, central banks, and governments, failed.

\section{Fiscal union - the future of the EU?}

When countries join monetary union, they give up one of two key economic policies: monetary policy, which increases the importance of fiscal policy and which should, inter alia, eliminate problems caused by the asymmetric effects of common monetary policy. Both policies act through demand; monetary policy presumably through interest rates, fiscal policy through managing budget expenditures and transfers to households. According to a prevalent opinion, the financial crisis confirmed views on the unsustainable simultaneity of a single monetary area and several fiscal areas in the EU. Rescuing those member 
countries in difficulties, in any area which is not an optimal currency area, is indeed possible only by siphoning money from prosperous countries to less successful ones, which is what the former dislike. The recent experience with Greece is an illuminating case showing that the fate of the euro and EMU depends on the fiscal future of the euro area and the EU.

It is unknown as to what the new fiscal arrangement should be; one can only guess at more or less plausible alternatives: fiscal shredding, increased fiscal coordination, and proper fiscal union (see Mencinger, 2011).

According to the first alternative - fiscal shredding - fiscal policy should remain the full responsibility of individual countries: they should renounce the receiving and providing of assistance in resolving financial problems in other countries. This approach reflects the belief that monetary union can work, if the EU renounces solidarity and mutual financial assistance.

According to the second alternative - increased fiscal coordination or fiscal pact - centralized monetary and decentralized fiscal policies are not mutually exclusive, if the latter are coordinated. In practice, however, fiscal coordination means that fiscal policy dictated by strong countries is self-evidently proper and generally applicable in all member countries irrespective of differences in development, the structure of economies, and economic conditions. This is actually happening: fiscal pact is the diktat of Germany imposing its fiscal conduct on other members of the monetary union. With regard to this, one should not overlook the fact that the global economic and financial crisis was not triggered by government deficits and public debts but by the private financial sector: it was caused by decades of income redistribution in favor of capital, the duplication of production capacities, and the providing for demand by means of credit. Thus, it cannot be resolved by austerity or imposed fiscal policies. Furthermore, unified fiscal policies synchronize and thus increase the volatility of economic activity by reducing the variety of policies and ensuing outcomes. Disciplining countries, which reduces demand and economic activity, can only deepen and prolong the crisis.

A third alternative - fiscal union - requires an accord on the division of tasks between different levels of government and, accordingly, the distribution of tax revenues between them. "Federation" or fiscal union is meaningful only if it enables efficient performance in accordance with the rules of fiscal federalism, if it decreases asymmetric effects of monetary policy, and at the same time diminishes regional disparities. However, it is not the task of this paper to dwell on the theoretical debate over fiscal federalism, the optimal distribution of tasks between the federation and its members and the corresponding distribution of tax revenues and transfers between them. The EU, such as it is and such as it will be, at least for the "fiscal framework" 2014-2020, is far from being a fiscal union. Indeed, fiscal union implies that the central government owns sufficient revenues by means of which it can neutralize asymmetric shocks caused by a single monetary policy, and enable the central budget to play the role of automatic stabilizer. The scope of the current flows of money on the revenue side of the EU budget (custom duties, participation in VAT and participation on GDP) and current outflows (common agricultural policy, cohesion and structural funds) on the expenditure side, does not allow that. The creation 
of proper fiscal union should radically increase the EU budget, introduce a "European" tax or ensure the participation of "federation" on tax revenues of the member states, and adopt the rules for horizontal distribution of public expenditure among member states. The system would be similar to the system of subsidizing municipalities in Slovenia or the equalization of the Länder in Germany (Konrad, Zschapitz, 2011).

The harmonization of taxes is already one of the most pressing issues of European integration; it should ensure the smooth functioning of a single market, as it is believed that taxes impede free trade and the free movement of factors of production, and that they affect the ability of individual member countries to gather large enough tax revenue if they depend on taxation in neighboring countries. For now, tax harmonization is limited to agreements on the basis of value added tax and minimum tax rates for the VAT taxation of alcohol, tobacco and energy as well as some arrangements regarding interaction between national tax systems. This brings us to discussion of the revenue side of universal basic income on the EMU and EU level.

\section{The introduction of UBI on EU and EMU levels}

Is the introduction of UBI on the EU and EMU level realistic? The first precondition for it is the creation of proper fiscal union, which implies radically increased revenues for the EU budget, the unification of tax rates, and the acceptance of rules for the distribution of tax revenues to EU citizens. Let us first look at the revenue side of it (Arcarons, Raventos and Torrens, 2014), or how to generate federal revenues, either by means a new "federal" tax or by the participation of the "federation" in existing direct or indirect taxes. Indirect taxes are undoubtedly a more suitable form of taxation to provide revenues of "federation" than direct taxes.

Though the calculations which follow are merely an exercise, they can indirectly indicate whether the creation of fiscal union and of UBI on the European level is possible or just an illusion. The probability of creating a "federation" and establishing UBI on the European level namely depends on the size of income redistributions among member countries. The first step in creating fiscal union is the unification of tax rates ${ }^{4}$. The average rate of indirect taxes in the EU-27 and EMU was 13.5 percent; the average EU citizen paid $€ 3,364$ per year in indirect taxes, while the average citizen of the euro area paid $€ 3,716$. The lowest 11 percent "effective" tax rate of indirect taxes was in Slovakia, the highest was 18.5 percent, in Cyprus; a resident of Luxembourg paid $€ 9,717$ and a resident of Bulgaria paid $€ 670$.

\footnotetext{
${ }^{4}$ The term "effective" tax rate is simply the share of tax revenues from indirect taxes in the GDP of a country; the shares are shown in Table 1a of the Appendix for EU27 and in Table 1b for the euro area. The calculations use data from the last pre-crisis year, i.e. 2008, which does not, however, affect the conclusions.
} 


\section{Graph 1: "Effective" tax rates in the EU27}

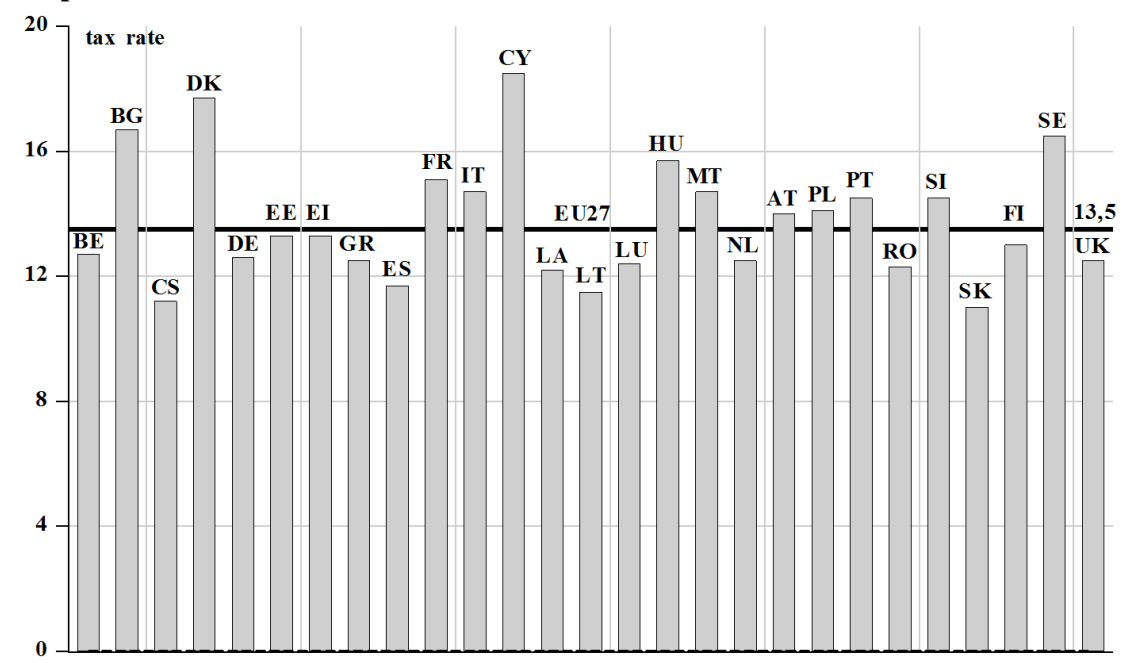

Source: Table $1 b$

Let us stay for now with the countries in the euro area, where the differences between the member states are fewer than the differences between the member states of the entire EU. How much more or less indirect taxes are to be paid by a resident in the euro area, if the tax rates in the area were put on the same footing, is shown in the third and fourth column of Table 1a of the Appendix. The tax burden would be reduced in seven and increased in ten member states of the euro area; it would be $€ 1,017$ lower in Cyprus, and $€ 849$ higher in Luxembourg. With the unification of tax rates in the EU27, a resident of Denmark would pay $€ 1,761$ less than under the existing national tax regime, while a resident of Luxembourg would pay €846 more.

The calculations which follow are based on the following assumptions. The participation of the "federation" (EMU or EU27) in the existing indirect taxes would amount to 50 percent of the revenues collected by indirect taxes in the member states. This would be $€ 608$ billion yearly in the euro area and $€ 835$ billion in the whole of the EU27. This assumption is actually close to the system which existed in the former Yugoslavia. According to this system, the revenues from customs duties (these are now a far less important form of revenues for the EU budget) belonged to the federal budget, revenues from sales tax (the predecessor of VAT) were shared between the federation and the republics, while direct taxes and social security contributions were determined at the level of the republics and belonged to them.

As indirect tax revenues in the EMU and EU account for about 13 percent of GDP, which implies a redistribution of only 6.5 percent of GDP, one could say that they would be extremely "slim" federations. Expenditure and revenue shares in actually functioning federations (US, Switzerland, Germany) in their GDP are several times larger. ${ }^{5}$

\footnotetext{
${ }^{5}$ The shares of expenditures of the central governments or of "federations" in 2008 were 20 percent of GDP in
} 
The results of the calculations are based on the assumption that the participation of "federation" in revenues amounts to 50 percent of indirect taxes and that the collected amount of money is distributed equally among all citizens in the form of UBI are presented in Table $2 \mathrm{a}$ and $3 \mathrm{a}$ for the euro area and in Table $2 \mathrm{~b}$ and $3 \mathrm{~b}$ for the EU27.

In the euro area, $€ 608$ billion collected by the center would be distributed to 328 million citizens; a citizen would obtain $€ 1,854$ a year, or $€ 154$ a month. The net gain or loss for a country is the difference between tax paid to and subsidies received from the central budget. It would, for example, in the case of Germany, amount to $€ 10.6$ billion or 0.44 percent of GDP. An average German citizen would pay $€ 1,989$ to the center and receive $€ 1,854$ as UBI, thus losing $€ 130$. Luxembourg would be the most affected country: the difference between contributions to the center and receipts from the center would amount to $€ 1,643$ million, or 4.37 percent of GDP, and the average citizen would lose $€ 3,425$ a year. The amount of redistribution under such an arrangement can better be seen by observing the effects which UBI would have on poor countries. Thus, UBI on the euro area level would mean that disposable income in Slovakia would increase 11.45 percent and in Estonia 8.97 percent of GDP, i.e. their citizens would respectively have $€ 1,169$ and $€ 1,061$ more.

\section{Graph 2: Net transfers in EU27}

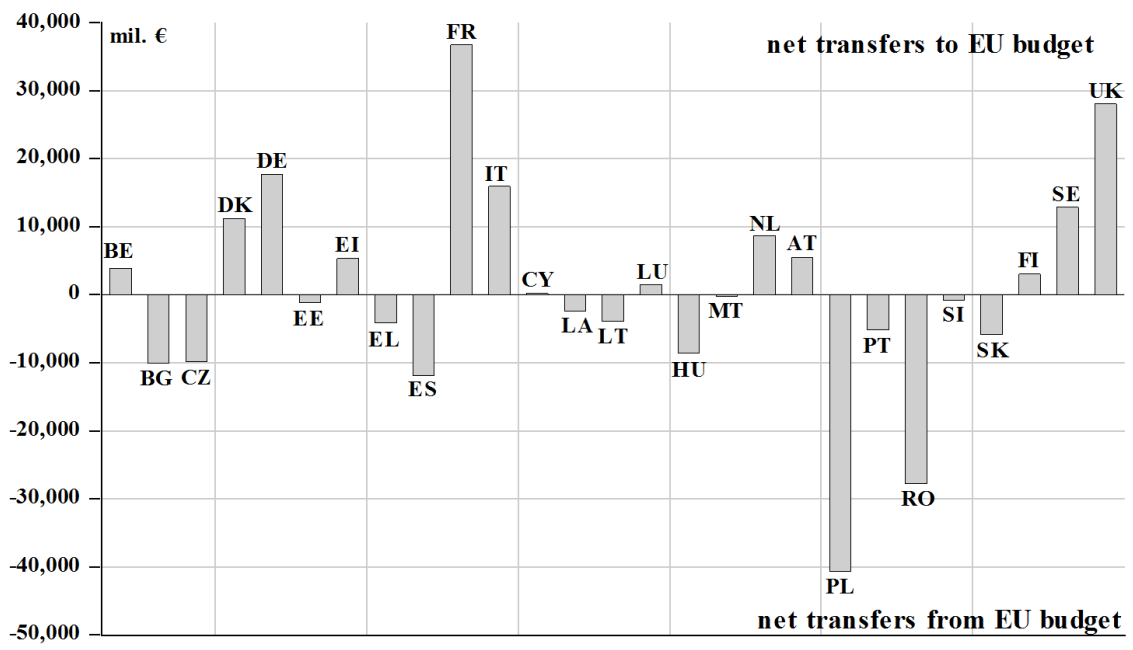

Source: Table $2 a$

the United States, 22.6 percent in Australia, 17.8 percent in Canada, and 17.3 percent in Switzerland. Due to transfers between different levels of government (and deficits), the shares of tax revenues differ from the shares of expenditure; in 2008, tax receipts of the federal government were 17.3 in the US, 27.8 in Australia, 16.7 in Canada and 16.1 in Switzerland; the EU's share of own taxes amounts to only 0.1 percent of GDP (El-Agra, 2011). 
Graph 3: Modest costs to the "North", hefty benefits to the "South"

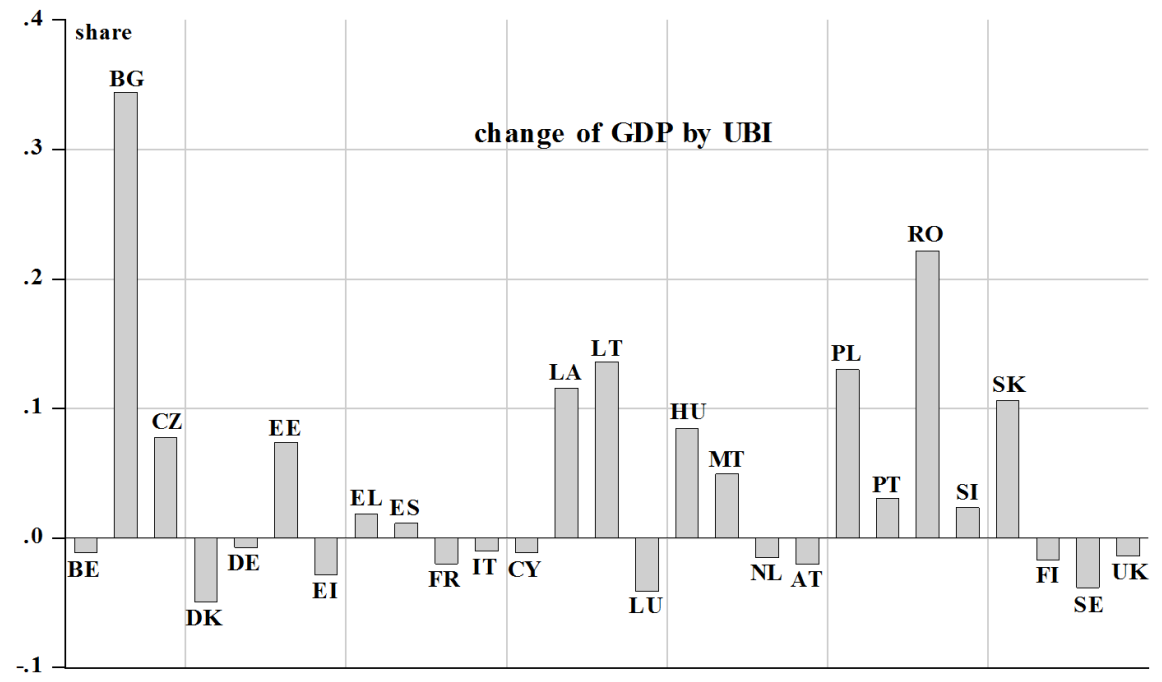

Source: Table $3 a$

In the EU27, €835 billion would be collected by the center and distributed to 495 million citizens; a citizen would obtain $€ 1,669$ in a year, or $€ 139$ in a month. The net gain or loss for a country is again the difference between taxes paid to and subsidies received from the central budget. In the case of Germany, the transfer of taxes to the "federal" budget amounts to $€ 163$ billion, while the transfers from it would be $€ 138$ billion, the, net transfers would amount to minus $€ 25$ billion, or 1.03 percent of GDP. The average citizen of Germany would pay $€ 1,988$ and receive $€ 1,669$ in the form of UBI; the yearly "loss" would be $€ 319$. The extremes are again Luxembourg, which would lose 4.59 percent of GDP, and Bulgaria, which would receive an unimaginable 35.1 percent of GDP; a Bulgarian citizen could annually spend $€ 1,383$ more than now.

\section{Conclusion}

The idea of universal basic income in different varieties has appeared in many countries in different forms: as pilot programs (Canada, Namibia, India), cash transfers (Alaska, Brazil) party programs, UBI associations, or theoretical discussions. The world economic crisis has increased interest in the concept. Some affordability studies on national levels have been conducted, for example, in Slovenia (Korošec, 2010) or in Ireland (Seán Healy et al., 2012) which suggested that UBI leading to an improvement in income for the majority of the population could be affordable with a 45 percent income tax rate.

The exercise on the affordability of UBI on the European level presented here is much more modest, limited and artificial. It only looks at the revenue side of UBI and does not consider indirect economic effects such as the increase in aggregate demand, and even 
less the social effects of any public services UBI replaces or could replace, or other issues such as the long-term political and social stability of the EU, migration flows, etc. Indeed, it is a kind of an initial test of the political affordability of the concept.

As stated above, the likelihood of UBI on the European level depends on the amount of the required redistribution: the larger the redistribution, the lower the chance. In the exercise, a rather "slim federation" would, by means of indirect taxes, collect and redistribute 6.5 percent of GDP. The amount of money required is calculated assuming that the center participates and collects 50 percent of tax revenues generated by existing indirect taxes (VAT and excise tax) and that this money is distributed equally to all citizens in the EU or in the euro area. This would allow a UBI of $€ 1,855$ per year or $€ 154$ per month if used in the euro area, and $€ 1,669$ per year or $€ 139$ per month if used in the EU28. Net costs in the rich countries would be relatively modest, while benefits in poor countries would be hefty. In the euro zone case, Germany would suffer a net "loss" of $€ 10.6$ billion or 0.44 percent of GDP, and the average German citizen would lose $€ 130$. On the other hand, disposable income in Slovakia would increase by 11.45 percent of GDP, and the average Bulgarian would have $€ 1,169$ more. By introducing UBI on the EU level, German net transfers would amount to minus $€ 25$ billion or 1.03 percent of GDP, and the "damage" to the average German would be $€ 319$ yearly.

Thus, one can say that UBI on the European level is an economically feasible and socially desirable solution which would enhance the long-term stability and persistence of European associations. However, the required redistribution is politically unacceptable in an association in which politicians argue over one percent of one percent. The experience of Greece or the behavior of EU "statesmen" in the refugee crisis clearly indicate that solidarity in Europe is far beyond the level required for introduction of UBI. The so-called structural reforms point in the opposite direction and solutions are sought in austerity, the reduction of the public sector, labor market flexibility, and privatization of education, health and social security, thus undermining social rights already acquired.

\section{References}

Arcarons, J., Raventos, P. D. and Torrens M. L. (2014). Feasibility of Financing a Basic Income. Basic Income Studies, 9(1-2), 79-93.

El-Agra, A. M. (2011). The European Union, Economics and Policies. Cambridge University Press.

Gilroy, B., Heimann, A. and Schopf, M. (2013). Basic Income and Labour Supply: The German Case. Basic Income Studies, 8(1), 43-70.

Healy, S., Murphy, M., Ward, S. and Reynolds, B. (2012). Basic Income - Why and How in Difficult Economic Times: Financing a BI in Ireland. BIEN Congress Munich 14th September 2012.

Konrad, K. A., Zschapitz, H. (2011). The Future of the Eurozone. CESifo Forum, 46-49. Korošec, V. (2010). Predlog UTD v Sloveniji - zakaj in kako, (Proposal for UBI in Slovenia - why and how). Delovni zvezek UMAR, 6/2010. 
Mencinger, J. (2011). Evro, fiskalni pakt, fiskalna unija (Euro, fiscal pact, fiscal union). Gospodarska Gibanja, (Economic Trends), 441, November 2011, 17-30.

Munger, M. C. (2012). Basic Income Is Not an Obligation, But It Might Be a Legitimate Choice. Basic Income Studies, 6(2), 1-13.

Pribac, I. (2004). Brezplačno kosilo za vse?, (Free Lunch for All?). Krtina. Ljubljana, 2004.

Standing, G. (2012). Why a Basic Income Is Necessary for a Right to Work? Basic Income Studies, 7(2), 19-40.

van Parijs, P. (2012). What's Wrong with a Free Lunch? Beacon Press.

Zwolinski, M. (2012). Classical Liberalism and the Basic Income. Basic Income Studies, 6(2), 1-14. 
DOI: 10.1515/danb-2015-0010

\section{Appendix A}

Table 1a: What would unification of tax rates mean in the euro area?

\begin{tabular}{|c|c|c|c|c|}
\hline 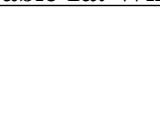 & $\begin{array}{l}\text { current system } \\
\text { "effective" } \\
\text { tax rate }\end{array}$ & $\begin{array}{l}\text { current system } \\
\text { tax/resident } €\end{array}$ & $\begin{array}{c}\text { average EU } \\
\text { tax rate } \\
\text { tax/resident } €\end{array}$ & $\begin{array}{c}\text { difference } \\
€\end{array}$ \\
\hline EMU & 0.1348 & 3716 & 3716 & 0 \\
\hline Belgium & 0.127 & 4017 & 4264 & 248 \\
\hline Germany & 0.126 & 3714 & 3975 & 260 \\
\hline Estonia & 0.133 & 1573 & 1594 & 22 \\
\hline Ireland & 0.133 & 5777 & 5856 & 79 \\
\hline Greece & 0.125 & 2538 & 2738 & 200 \\
\hline Spain & 0.117 & 2752 & 3171 & 419 \\
\hline France & 0.151 & 4474 & 3995 & -479 \\
\hline Italy & 0.147 & 3825 & 3508 & -317 \\
\hline Cyprus & 0.185 & 3756 & 2737 & -1018 \\
\hline Luxembourg & 0.124 & 9717 & 10566 & 849 \\
\hline Malta & 0.147 & 1960 & 1798 & -162 \\
\hline Netherlands & 0.125 & 4348 & 4690 & 342 \\
\hline Austria & 0.140 & 4598 & 4428 & -170 \\
\hline Portugal & 0.145 & 2312 & 2150 & -162 \\
\hline Slovenia & 0.145 & 2484 & 2310 & -174 \\
\hline Slovakia & 0.110 & 1123 & 1377 & 254 \\
\hline Finland & 0.130 & 4430 & 4594 & 165 \\
\hline
\end{tabular}

Source: Eurostat, own calculations 
Table 1b: What would unification of tax rates bring in EU27?

\begin{tabular}{|l|c|c|c|c|}
\hline & $\begin{array}{c}\text { current system } \\
\text { "effective" } \\
\text { tax rate }\end{array}$ & $\begin{array}{c}\text { current system } \\
\text { tax/resident } €\end{array}$ & $\begin{array}{c}\text { average EU } \\
\text { tax rate } \\
\text { tax/resident } €\end{array}$ & $\begin{array}{c}\text { difference } \\
€\end{array}$ \\
\hline EU27 & 0.135 & 3364 & 3364 & 0 \\
\hline Belgium & 0.127 & 4016 & 4263 & 247 \\
\hline Bulgaria & 0.167 & 670 & 541 & -129 \\
\hline Czech Republic & 0.112 & 1376 & 1656 & 280 \\
\hline Denmark & 0.177 & 7387 & 5626 & -1761 \\
\hline Germany & 0.126 & 3714 & 3973 & 259 \\
\hline Estonia & 0.133 & 1572 & 1593 & 21 \\
\hline Ireland & 0.133 & 5777 & 5855 & 78 \\
\hline Greece & 0.125 & 2538 & 2737 & 199 \\
\hline Spain & 0.117 & 2752 & 3171 & 418 \\
\hline France & 0.151 & 4474 & 3994 & -480 \\
\hline Italy & 0.147 & 3825 & 3507 & -317 \\
\hline Cyprus & 0.185 & 3755 & 2736 & -1019 \\
\hline Latvia & 0.122 & 1133 & 1252 & 119 \\
\hline Lithuania & 0.115 & 976 & 1144 & 168 \\
\hline Luxembourg & 0.124 & 9717 & 10564 & 846 \\
\hline Hungary & 0.157 & 1573 & 1350 & -222 \\
\hline Malta & 0.147 & 1960 & 1797 & -163 \\
\hline Netherlands & 0.125 & 4348 & 4689 & 341 \\
\hline Austria & 0.140 & 4597 & 4427 & -171 \\
\hline Poland & 0.141 & 1153 & 1102 & -51 \\
\hline Portugal & 0.145 & 2312 & 2149 & -163 \\
\hline Romania & 0.123 & 715 & 783 & 69 \\
\hline Slovenia & 0.145 & 2484 & 2309 & -175 \\
\hline Slovakia & 0.110 & 1123 & 1376 & 253 \\
\hline Finland & 0.130 & 4429 & 4593 & 164 \\
\hline Sweden & 0.165 & 6109 & 4991 & $-1,118$ \\
\hline UK & 0.125 & 4207 & 4537 & 330 \\
\hline Source: & & & \\
\hline
\end{tabular}

Source: Eurostat, own calculations 
DOI: 10.1515/danb-2015-0010

Table 2a: Effects of UBI on redistribution - EMU country level

\begin{tabular}{|l|r|r|r|r|r|r|r|}
\hline & $\begin{array}{c}\text { indirect } \\
\text { taxes } \\
\text { million } €\end{array}$ & $\begin{array}{c}\text { transfers } \\
\text { to EU } \\
\text { budget } \\
\text { million } €\end{array}$ & $\begin{array}{c}\text { transfers } \\
\text { from } \\
\text { EU budget } \\
\text { million } €\end{array}$ & $\begin{array}{c}\text { difference } \\
\text { million } €\end{array}$ & $\begin{array}{c}\text { \% of } \\
\text { country } \\
\text { BDP }\end{array}$ & $\begin{array}{c}\text { share in } \\
\text { transfers } \\
\text { to EMU } \\
\text { budget }\end{array}$ & $\begin{array}{c}\text { share in } \\
\text { transfers } \\
\text { from EMU } \\
\text { budget }\end{array}$ \\
\hline EMU & 1216749 & 608376 & 608376 & 0 & 0 & 100.00 & 100.00 \\
\hline Belgium & 45293 & 22646 & 19733 & -2914 & -0.87 & 3.72 & 3.24 \\
\hline Germany & 326971 & 163486 & 152825 & -10660 & -0.44 & 26.87 & 25.12 \\
\hline Estonia & 2140 & 1070 & 2494 & 1424 & 8.97 & 0.18 & 0.41 \\
\hline Ireland & 25565 & 12783 & 8110 & -4673 & -2.46 & 2.10 & 1.33 \\
\hline Greece & 30646 & 15323 & 20794 & 5471 & 2.41 & 2.52 & 3.42 \\
\hline Spain & 142310 & 71155 & 83364 & 12209 & 1.16 & 11.70 & 13.70 \\
\hline France & 254807 & 127404 & 118489 & -8915 & -0.47 & 20.94 & 19.48 \\
\hline Italy & 208300 & 104150 & 110304 & 6154 & 0.40 & 17.12 & 18.13 \\
\hline Cyprus & 2146 & 1073 & 1456 & 384 & 2.41 & 0.18 & 0.24 \\
\hline Luxembourg & 5070 & 2535 & 891 & -1643 & -4.37 & 0.42 & 0.15 \\
\hline Malta & 735 & 368 & 760 & 392 & 7.19 & 0.06 & 0.12 \\
\hline Netherlands & 76814 & 38407 & 30427 & -7980 & -1.40 & 6.31 & 5.00 \\
\hline Austria & 36757 & 18378 & 15421 & -2957 & -1.08 & 3.02 & 2.53 \\
\hline Portugal & 22807 & 11403 & 19707 & 8304 & 4.91 & 1.87 & 3.24 \\
\hline Slovenia & 4664 & 2332 & 3751 & 1419 & 4.10 & 0.38 & 0.62 \\
\hline Slovakia & 7431 & 3715 & 10025 & 6310 & 11.45 & 0.61 & 1.65 \\
\hline Finland & 24298 & 12149 & 9825 & -2324 & -1.29 & 2.00 & 1.61 \\
\hline SOurce: & & & & & & \\
\hline
\end{tabular}

Source: Eurostat, own calculations 
Table 2b: Effects of UBI on redistribution - EU country level

\begin{tabular}{|l|r|r|r|r|r|r|r|}
\hline & $\begin{array}{c}\text { indirect } \\
\text { taxes } \\
\text { millions } \\
€\end{array}$ & $\begin{array}{c}\text { transfers } \\
\text { to EU } \\
\text { budget } \\
\text { mil. } €\end{array}$ & $\begin{array}{c}\text { transfers } \\
\text { from } \\
\text { EU budget } \\
\text { mil. } €\end{array}$ & $\begin{array}{c}\text { difference } \\
\text { million } €\end{array}$ & $\begin{array}{c}\text { of } \\
\text { country } \\
\text { BDP }\end{array}$ & $\begin{array}{c}\text { share in } \\
\text { transfers } \\
\text { from EU27 } \\
\text { budget }\end{array}$ & $\begin{array}{c}\text { share in } \\
\text { transfers } \\
\text { to EU27 } \\
\text { budget }\end{array}$ \\
\hline EU27 & 1669972 & 835087 & 835087 & 0 & 0 & 100.00 & 100.00 \\
\hline Belgium & 45283 & 22642 & 17867 & -4775 & -1.42 & 2.16 & 2.71 \\
\hline Bulgaria & 4147 & 2073 & 12884 & 10810 & 35.14 & 1.52 & 0.25 \\
\hline Czech republic & 17095 & 8548 & 17363 & 8816 & 6.95 & 2.09 & 1.02 \\
\hline Denmark & 30717 & 15359 & 9184 & -6174 & -2.71 & 1.11 & 1.84 \\
\hline Germany & 326901 & 163450 & 138374 & -25077 & -1.03 & 16.64 & 19.57 \\
\hline Estonia & 2140 & 1070 & 2258 & 1188 & 7.49 & 0.27 & 0.13 \\
\hline Ireland & 25560 & 12780 & 7343 & -5437 & -2.87 & 0.90 & 1.53 \\
\hline Greece & 30640 & 15320 & 18827 & 3508 & 1.54 & 2.26 & 1.83 \\
\hline Spain & 142280 & 71140 & 75481 & 4341 & 0.41 & 9.24 & 8.52 \\
\hline France & 254752 & 127376 & 107284 & -20092 & -1.06 & 12.58 & 15.25 \\
\hline Italy & 208255 & 104127 & 99873 & -4254 & -0.28 & 11.87 & 12.47 \\
\hline Cyprus & 2145 & 1073 & 1319 & 246 & 1.55 & 0.16 & 0.13 \\
\hline Latvia & 2850 & 1425 & 3828 & 2404 & 11.37 & 0.44 & 0.17 \\
\hline Lithuania & 3864 & 1932 & 5678 & 3746 & 13.07 & 0.65 & 0.23 \\
\hline Luxembourg & 5068 & 2534 & 807 & -1727 & -4.59 & 0.10 & 0.30 \\
\hline Hungary & 13581 & 6790 & 16915 & 10125 & 10.05 & 2.05 & 0.81 \\
\hline Malta & 735 & 368 & 688 & 320 & 5.87 & 0.08 & 0.04 \\
\hline Netherlands & 76797 & 38399 & 27549 & -10849 & -1.90 & 3.32 & 4.60 \\
\hline Austria & 36749 & 18374 & 13963 & -4411 & -1.62 & 1.68 & 2.20 \\
\hline Poland & 42020 & 21010 & 64115 & 43105 & 13.83 & 7.72 & 2.52 \\
\hline Portugal & 22802 & 11401 & 17844 & 6443 & 3.81 & 2.14 & 1.37 \\
\hline Romania & 16871 & 8436 & 36227 & 27791 & 22.20 & 4.18 & 1.01 \\
\hline Slovenia & 4663 & 2331 & 3396 & 1065 & 3.08 & 0.41 & 0.28 \\
\hline Slovakia & 7429 & 3714 & 9077 & 5363 & 9.73 & 1.09 & 0.44 \\
\hline Finland & 24293 & 12147 & 8896 & -3250 & -1.80 & 1.07 & 1.45 \\
\hline Sweden & 45663 & 22831 & 15388 & -7444 & -2.20 & 1.86 & 2.73 \\
\hline UK & 276735 & 138368 & 102583 & -35785 & -1.74 & 12.46 & 16.57 \\
\hline Source: Eurat & & & & & & \\
\hline
\end{tabular}

Source: Eurostat, own calculations 
DOI: 10.1515/danb-2015-0010

Table 3a: Effects of UBI on redistribution in EMU - citizen level

\begin{tabular}{|l|c|c|c|c|c|}
\hline & $\begin{array}{c}\text { share of } \\
\text { EMU } \\
\text { population } \\
\%\end{array}$ & $\begin{array}{c}\text { population } \\
\text { millions }\end{array}$ & $\begin{array}{c}\text { indirect } \\
\text { taxes } \\
\text { paid by } \\
\text { citizen } €\end{array}$ & $\begin{array}{c}\text { taxes } \\
\text { transferred } \\
\text { to EU } \\
\text { budget } €\end{array}$ & $\begin{array}{c}\text { difference } \\
\text { between } \\
\text { transfers to } \\
\text { and UBI } €\end{array}$ \\
\hline EMU & 100.00 & 327.70 & 3710 & 1855 & 0 \\
\hline Belgium & 3.24 & 10.66 & 4273 & 2136 & -274 \\
\hline Germany & 25.12 & 82.22 & 3978 & 1989 & -130 \\
\hline Estonia & 0.41 & 1.34 & 1634 & 817 & 1.061 \\
\hline Ireland & 1.33 & 4.46 & 5732 & 2866 & -1.070 \\
\hline Greece & 3.42 & 11.18 & 2741 & 1371 & 489 \\
\hline Spain & 13.70 & 45.67 & 3116 & 1558 & 272 \\
\hline France & 19.48 & 62.14 & 3981 & 1991 & -140 \\
\hline Italy & 18.13 & 58.65 & 3552 & 1776 & 104 \\
\hline Cyprus & 0.24 & 0.78 & 2751 & 1376 & 489 \\
\hline Luxembourg & 0.15 & 0.48 & 10563 & 5281 & -3.425 \\
\hline Malta & 0.12 & 0.41 & 1795 & 898 & 959 \\
\hline Netherlands & 5.00 & 16.41 & 4681 & 2340 & -487 \\
\hline Austria & 2.53 & 8.31 & 4423 & 2212 & -356 \\
\hline Portugal & 3.24 & 10.55 & 2162 & 1081 & 783 \\
\hline Slovenia & 0.62 & 2.01 & 2320 & 1160 & 703 \\
\hline Slovakia & 1.65 & 5.38 & 1381 & 691 & 1.169 \\
\hline Finland & 1.61 & 5.30 & 4585 & 2292 & -439 \\
\hline Source: & & & & & \\
\hline
\end{tabular}

Source: Eurostat, own calculation 
Table 3b: Effects of UBI on redistribution in EU - citizen level

\begin{tabular}{|l|c|c|c|c|c|}
\hline & $\begin{array}{c}\text { share of } \\
\text { EU } \\
\text { population } \\
\%\end{array}$ & $\begin{array}{c}\text { population } \\
\text { millions }\end{array}$ & $\begin{array}{c}\text { indirect } \\
\text { taxes } \\
\text { paid by } \\
\text { a citizen } €\end{array}$ & $\begin{array}{c}\text { taxes } \\
\text { transferred } \\
\text { to EU } \\
\text { budget } €\end{array}$ & $\begin{array}{c}\text { difference } \\
\text { between } \\
\text { transfers to } \\
\text { and UBI } €\end{array}$ \\
\hline EU27 & 100.00 & 494.3 & 3337 & 1669 & 0 \\
\hline Belgium & 2.14 & 10.66 & 4248 & 2124 & -455 \\
\hline Bulgaria & 1.54 & 7.52 & 551 & 276 & 1393 \\
\hline Czech republic & 2.08 & 10.34 & 1653 & 827 & 842 \\
\hline Denmark & 1.10 & 5.48 & 5605 & 2803 & -1134 \\
\hline Germany & 16.57 & 82.22 & 3976 & 1988 & -319 \\
\hline Estonia & 0.27 & 1.34 & 1597 & 799 & 870 \\
\hline Ireland & 0.88 & 4.46 & 5731 & 2865 & -1196 \\
\hline Greece & 2.25 & 11.18 & 2741 & 1370 & 299 \\
\hline Spain & 9.04 & 45.67 & 3115 & 1558 & 111 \\
\hline France & 12.85 & 62.14 & 4100 & 2050 & -381 \\
\hline Italy & 11.96 & 58.65 & 3551 & 1775 & -106 \\
\hline Cyprus & 0.16 & 0.78 & 2750 & 1376 & 293 \\
\hline Latvia & 0.46 & 2.19 & 1301 & 651 & 1018 \\
\hline Lithuania & 0.68 & 3.21 & 1204 & 602 & 1067 \\
\hline Luxembourg & 0.10 & 0.48 & 10558 & 5279 & -3610 \\
\hline Hungary & 2.03 & 10.11 & 1343 & 672 & 997 \\
\hline Malta & 0.08 & 0.41 & 1793 & 898 & 771 \\
\hline Netherlands & 3.30 & 16.41 & 4680 & 2340 & -671 \\
\hline Austria & 1.67 & 8.31 & 4422 & 2211 & -542 \\
\hline Poland & 7.68 & 38.12 & 1102 & 551 & 1118 \\
\hline Portugal & 2.14 & 10.55 & 2161 & 1081 & 588 \\
\hline Romania & 4.34 & 20.64 & 817 & 409 & 1260 \\
\hline Slovenia & 0.41 & 2.01 & 2320 & 1160 & 509 \\
\hline Slovakia & 1.09 & 5.38 & 1381 & 690 & 979 \\
\hline Finland & 1.07 & 5.3 & 4584 & 2292 & -623 \\
\hline Sweden & 1.84 & 9.18 & 4974 & 2487 & -818 \\
\hline UK & 12.29 & 61.57 & 4495 & 2247 & -578 \\
\hline Source: Eurostat & 0496 & & \\
\hline
\end{tabular}

Source: Eurostat, own calculations 